$\mathcal{E}_{\text {International }}^{\text {Insport Forum }}$

\title{
Time Efficiency at World Container Ports
}

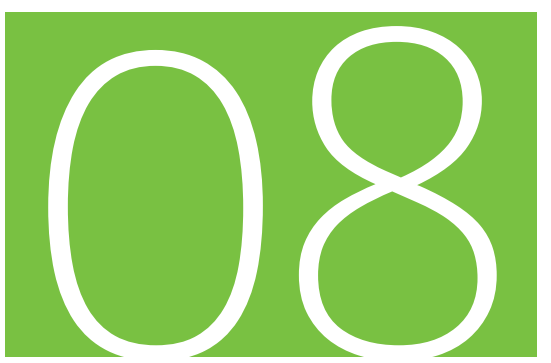

Discussion Paper 2014・08

César Ducruet

Centre National de la Recherche Scientifique (CNRS), Paris, France

Hidekazu Itoh

School of Business Administration, Kwansei Gakuin University,

Nishinomiya, Japan

Olaf Merk

International Transport Forum, Paris, France 


\title{
International Transport Forum
}

\section{Time Efficiency at World Container Ports}

\author{
Discussion Paper No. 2014-08
}

\section{César DUCRUET,}

Centre National de la Recherche Scientifique (CNRS), Paris, France

Hidekazu ITOH,

School of Business Administration, Kwansei Gakuin University, Nishinomiya, Japan

Olaf MERK,

International Transport Forum, Paris, France

August 2014 
The International Transport Forum at the OECD is an intergovernmental organisation with 54 member countries. It acts as a strategic think-tank, with the objective of helping shape the transport policy agenda on a global level and ensuring that it contributes to economic growth, environmental protection, social inclusion and the preservation of human life and well-being. The International Transport Forum organises an annual summit of Ministers along with leading representatives from industry, civil society and academia.

The International Transport Forum was created under a Declaration issued by the Council of Ministers of the ECMT (European Conference of Ministers of Transport) at its Ministerial Session in May 2006 under the legal authority of the Protocol of the ECMT, signed in Brussels on 17 October 1953, and legal instruments of the OECD.

The Members of the Forum are: Albania, Armenia, Australia, Austria, Azerbaijan, Belarus, Belgium, Bosnia and Herzegovina, Bulgaria, Canada, Chile, People's Republic of China, Croatia, Czech Republic, Denmark, Estonia, Finland, France, Former Yugoslav Republic of Macedonia, Georgia, Germany, Greece, Hungary, Iceland, India, Ireland, Italy, Japan, Korea, Latvia, Liechtenstein, Lithuania, Luxembourg, Malta, Mexico, Republic of Moldova, Montenegro, the Netherlands, New Zealand, Norway, Poland, Portugal, Romania, Russian Federation, Serbia, Slovak Republic, Slovenia, Spain, Sweden, Switzerland, Turkey, Ukraine, United Kingdom and United States.

The International Transport Forum's Research Centre gathers statistics and conducts co-operative research programmes addressing all modes of transport. I ts findings are widely disseminated and support policymaking in Member countries as well as contributing to the annual summit.

\section{Discussion Papers}

The International Transport Forum's Discussion Paper Series makes economic research, commissioned or carried out at its Research Centre, available to researchers and practitioners. The aim is to contribute to the understanding of the transport sector and to provide inputs to transport policy design.

ITF Discussion Papers should not be reported as representing the official views of the ITF or of its member countries. The opinions expressed and arguments employed are those of the authors.

Discussion Papers describe preliminary results or research in progress by the author(s) and are published to stimulate discussion on a broad range of issues on which the ITF works. Comments on Discussion Papers are welcomed, and may be sent to: International Transport Forum/OECD, 2 rue André-Pascal, 75775 Paris Cedex 16, France.

For further information on the Discussion Papers and other JTRC activities, please email: itf.contact@oecd.org

The Discussion Papers can be downloaded from:

www. internationaltransportforum. org/jtrc/DiscussionPapers/jtrcpapers.html

The International Transport Forum's website is at: www. internationaltransportforum.org

This document and any map included herein are without prejudice to the status of or sovereignty over any territory, to the delimitation of international frontiers and boundaries and to the name of any territory, city or area. 
TABLE OF CONTENTS

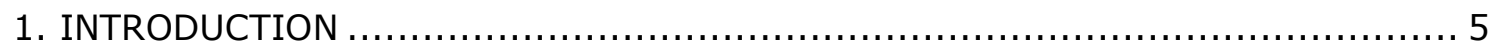

2. THE TIME FACTOR IN PORT PERFORMANCE AND EFFICIENCY $\ldots \ldots \ldots \ldots \ldots \ldots \ldots 6$

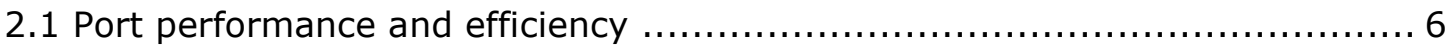

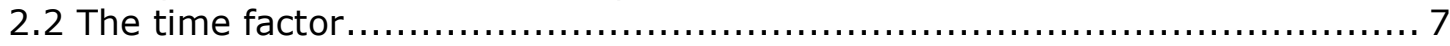

3. DATA AND METHODOLOGY FOR A GLOBAL ANALYSIS OF TIME EFFICIENCY ......9

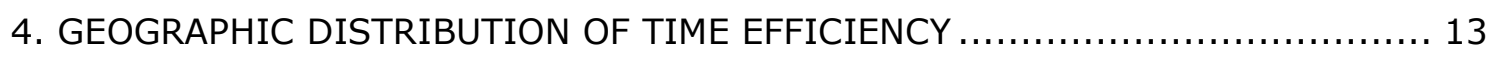

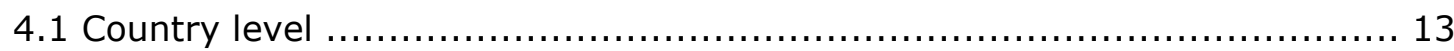

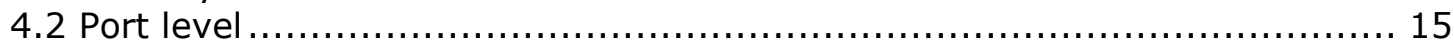

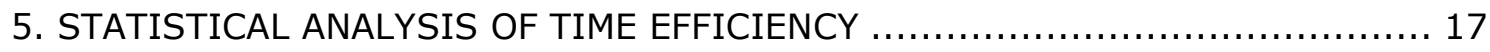

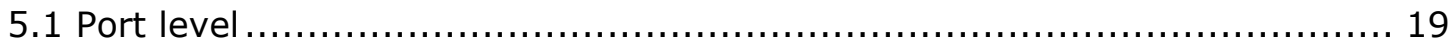

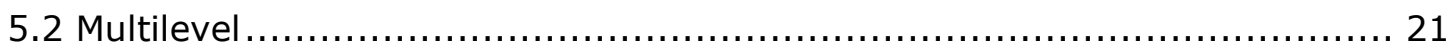

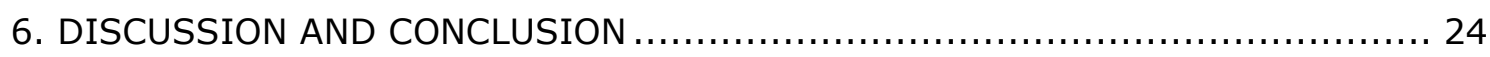

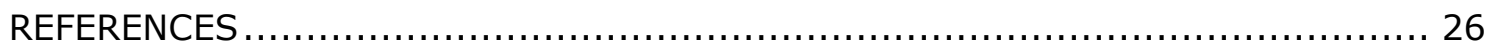





\section{INTRODUCTION}

The ability of ports to ensure efficient cargo transfers is one central dimension of their overall function as transport nodes. Before containerization, such as in the late nineteenth century, large seaports were already competing in their attempt providing fast transit between sea and land, in a context of growing global trades (Marnot, 2012). Such aspects are even more crucial nowadays when the port can be considered as only one element of value-driven supply chains (Robinson, 2002) or as a set of independent terminals operated by global actors (Olivier and Slack, 2006). While port efficiency as a whole may be understood from various perspectives, its influence on trade facilitation (Clark et al., 2004) and regional development (Haddad et al., 2010) has been well underlined. Ways to measure port efficiency and performance are very diverse, but the time factor has been so far largely left aside, especially in international comparative studies of ports. More frequent are case studies of specific aspects such as fast-ship services (De Langen, 1999), broader approaches such as the global synchronization of transport terminals in a context of space/time collapse (Rodrigue, 1999), or operations research about queuing models of vessels in relation to port entrance channels and berth allocation and productivity. A geography of time efficiency thus remains missing, although it would provide a better understanding of port operations as a whole and, to some extent, of the territories where such ports are located. This exercise would also contribute to further discussing the geographical dimension of port operations, beyond sole technical and economic factors ( $\mathrm{Ng}$ and Ducruet, 2014). How are average turnaround times distributed across the globe; can its determinants be highlighted? This paper hypothesizes that beyond individual situations, the time efficiency levels of individual ports might exhibit certain commonalities functionally and/or regionally. The scattered dimension of existing works made of monographs and small port samples has not been able to answer such crucial questions satisfactorily.

In addition to such gaps, research remains hampered by missing information on time efficiency itself, as underlined by De Langen et al. (2007, p. 31): "even though ship turnaround time is already discussed in academic literature for more than 30 years (...), no port systematically reports the ship turnaround times. This turnaround time includes the time spent with entering the port, loading, unloading, and departing. Even though this is clearly relevant for shipping lines [in terms of related port costs], ports do not report turnaround times in annual reports or other publications". And even if it possible to qualify these statements - as various ports collect data on vessel turnaround times, and the maritime industry itself also provides various time-related metrics - the lack of a systematic and comparative study on vessel turnaround times in ports remains striking. Time efficiency thus poses both analytical and methodological issues that need to be resolved before going further. This paper aims to fill this gap, by presenting an overview of time efficiency in world container ports in 1996, 2006, and 2011. It tries to identify relations with possible determinants of time efficiency, such as the volume of traffics, size of vessels, and other indicators about the situation of ports in the global liner shipping network. Section 2 provides a literature review with background on existing studies on port performance and efficiency studies. Section 3 presents the methodology and datasets used for this paper. Section 4 presents the geographical distribution of time efficiency, Section 5 a statistical analysis and Section 6 is a brief conclusion. 


\section{THE TIME FACTOR IN PORT PERFORMANCE AND EFFICIENCY}

\subsection{Port performance and efficiency}

Numerous port performance indicators (PPIs) have been proposed since the seminal works of United Nations (UNCTAD, 1976) and De Monie (1987) (Table 1). Since then, the number of port performance studies has increased tremendously, applying various methods to small samples of ports worldwide (see Chung, 1993; Poitras et al., 1996). Size of port infrastructure and traffic volume are the most widely accessible indicators internationally. For the rest, there is a wide diversity of measures and methods among ports of the world (De Langen et al., 2007). Beyond the transfer of cargo, operational indicators are not often used in the scholarly literature. Port throughput volumes may be analyzed in various ways, such as divided by the length of quays to measure productivity or by the total throughput of a given port range or maritime region to measure a market share. The precise modal split, monetary value, and hinterland geographic distribution of traffics remain, however, often inaccessible on a large scale (Itoh, 2013).

More likely are measures of the size and quality of port infrastructures. The size of the port is a very rough indicator since it does not directly refer to performance but to the total length or surface of port areas, regardless of their utilisation (cf. basins, terminals, warehouses, port authority buildings, ramps and various tracks) but which can be distributed by handling or commodity type. The maximum water depth at port terminals, the depth of the navigation channel, and the number of twenty-foot equivalent units (TEUs) per gantry berth are useful indicators (Itoh et al., 2003; Tongzon, 2004) that go beyond the sole natural conditions of the site. Other indicators describing the available handling facilities in ports can also be found, such as the surface of storage areas and warehouses, the number of reefer plugs (refrigerated containers), and the counting of handling facilities (e.g. cranes, straddle carriers, etc.). Several works have classified ports based on their physical characteristics, since the seminal work of Tongzon (1995) on performance indicators using multivariate analysis, such as Itoh (2002), Wang et al. (2003), Joly and Martell (2003), Cullinane and Wang (2006), Herrera and Pang (2006), and Wu and Goh (2010) among many others (see also Talley, 1994; Tongzon and Ganesalingam, 1994).

\section{Table 1. Original performance indicators proposed by UNCTAD (1976)}

\begin{tabular}{|l|l|}
\hline \multicolumn{1}{|c|}{ Financial indicators } & \multicolumn{1}{c|}{ Operational indicators } \\
\hline Tonnage worked & Arrival date \\
Berth occupancy revenue per ton of cargo & Waiting time \\
Cargo handling revenue per ton of cargo & Service time \\
Labour expenditure & Turn-around time \\
Capital equipment expenditure per ton of cargo & Tonnage per ship \\
Contribution per ton of cargo & Fraction of time berthed ships worked \\
Total contribution & Number of gangs employed per ship per shift \\
& Tons per ship-hour in port \\
& Tons per ship hour at berth \\
& Tons per gang hours \\
& Fraction of time gangs idle \\
\hline
\end{tabular}

Source: Own elaboration 
Other works have put more emphasis on economic indicators, although they often remain difficult to access, such as the monetary and added value of cargo throughput (Lemarchand, 2000), or bound to subjective views approached through interviews with port authorities and transport firms $(\mathrm{Ng}, 2006)$ as well as shippers, forwarders, and shipping lines (Tongzon, 2002; Tiwari et al., 2003). Other studies included Supply Chain Management (SCM) aspects into port performance analysis (Bichou, 2006), environmental port performance indicators (Wooldridge et al., 2010) ${ }^{1}$, but also indicators about market trends and structure, socioeconomic impact, environmental performance, logistic chain and operational performance, and governance proposed by organizations such as ESPO ${ }^{2}$ and the PPRISM ${ }^{3}$ project. Such efforts have been undertaken to go beyond the sole physical approach to port development as well as the cost perspective. The latter includes port charges as well as terminal handling costs, which can be distinguished among ship-based costs (e.g. port navigation fees, berthage, berth hire, harbour dues, and tonnage) and cargo-based costs (e.g. wharfage and demurrage) as well as the ancillary charges of port services as noted by Tongzon (2002): pilotage, towage, lines, mooring/unmooring, electricity, water and garbage disposal ${ }^{4}$.

\subsection{The time factor}

The average turnaround time illustrates the capability of the port to efficiently handle cargo flows at the terminals and beyond. It can be defined as the average time a vessel needs to stay in a port (difference between time of entrance and time of departure). In the same category, the $d w e l l$ time is "the number of days a container can remain at a container terminal once it has been unloaded from a ship before incurring a storage fee" (Le-Griffin and Murphy, 2006). Port and terminal authorities can modify the container dwell time in order to gain space and increase the capacity of storage yards. There are inherent challenges to international comparison. First, different ports have different regulations in terms of hours of operation (i.e. number of hours and shifts that terminal gates are open). Again, authorities may extend such hours in order to increase their productivity without expanding existing infrastructure. However, there is a risk that stacking costs increase as the land utilisation rate increases. Transit time thus also relates with the other indicator of the number and frequency of ships visits. Second, official port statistics are not always clear about the exact meaning of turnaround time, i.e. whether it applies to the time spent inside the port or to the whole trip of the vessel including also the entrance channel and queuing time outside to/from the port. Thus, so-called productivity indicators are usually preferred such as by dividing port traffic volume per total length of quay. Le-Griffin and Murphy (2006) proposed various productivity indicators at crane, berth, yard, gate, and gang levels, while acknowledging the limited availability of such precise data internationally, except from berth length utilisation rate (TEUs per foot of container quay), crane utilisation rate (TEUs per container gantry crane), crane productivity (TEUs per container gantry crane-hour), and land area utilisation rate (TEUs per acre of terminal area). These indicators closely resemble the various performance metrics that can be acquired via specialised port consultancies, such as Drewry, and which include comparative information on utilisation rates (such as TEUs/year per crane, vessels/year per berth, TEUs per year per hectare and containers/hours per lane) as well as productivity (moves per crane-hour, vessel service time, truck time in terminal and number of gang moves per man-hour). These databases suggest that on average large

1. See also the ECOPORTS project (http://www.ecoports.com)

2. http://www.espo.be/pages/ezine.aspx?newsletter $=1369$

3. http://pprism.espo.be/PPRISMWorkPlan.aspx

4. For a review on the detailed explanation of handling costs and several examples in European and other worldwide container ports by trade routes and types of containers: http://ec.europa.eu/competition/sectors/transport/reports/terminal_handling_charges.pdf 
port terminals handle 110,000 TEU per crane, reach $25-40$ crane moves per hour, and have an average dwell time of import boxes of 5-7 days and export boxes of 3-5 days (Merk, 2013).

Transit time has, however, increasingly been integrated in studies of port performance, based on the fact "that customers are concerned not only with transport costs in selecting which carriers they will use and the routing undertaken, but also with a range of other factors including safety, traceability, reliability and transit times" as mentioned by Slack and Comtois (2013) in their study of ocean transit times. Besides more general discussions on such topics (Hummels 2001; Slack 1985; Djankov et al., 2005; Nordas et al., 2006; Tongzon and Savant 2007), some authors have proposed specific studies of container flows in liner shipping looking at congestion issues in ports (Notteboom, 2006; Verminen et al., 2007; Yan et al., 2009; Jones et al., 2011; Leachman and Payman, 2011, 2012) but also advanced methodological frameworks including all aspects of port and vessel operations of which total voyage time, voyage time at sea, voyage time in port, average port time, and vessel speed (Moon and Woo, 2013). The latter work is rooted in earlier studies of transit time performance of ocean carriers (Saldanha et al., 2006), notably those looking at time uncertainty in shipping and port operations (Wang and Meng, 2012; Qi and Song, 2012) and measurements of the time factor in liner shipping network design through mathematical modelling (Alvarez, 2012).

Suarez-Aleman et al. (2013) rightly argued that very few empirical studies have been made about time efficiency, although such aspect is known to be crucial and despite the possibility for inefficient ports to remain attractive for other reasons (Wilmsmeier et al., 2003). One early exception is the study by Edmond and Maggs (1976) of five United Kingdom ports, concluding that no simple linear relationship existed between ship size, handling rate and ship berth time, but one may argue that the study sample might have been too small for such a statistical approach. In the same vein, Heaver and Studer (1972) concluded that, for instance, many factors may blur the relationship between ship size and loading time, such as weather, labour, and market conditions, the importance of time to vessel operations, and the number of berth changes, but overall, their study of Vancouver demonstrated a solid correspondence between the two variables. Indeed and as suggested by Goss (1967) in his study of turnaround times, a vast literature had already addressed such issues back in the 1950 s with the objective to finds ways to reduce excessive port time and overall sea transport costs. More recent studies include the search for factors influencing time efficiency in Latin American ports, such as container loading rate, containers loaded per vessel, and waiting times (Sanchez et al., 2003), the analysis of the relationship between port characteristics (of which cargo delay during customs procedures) and maritime transport costs (Wilmsmeier et al., 2006), and the detailed analysis of the components of vessel time in ports and the determinants of port inefficiency, such as customs clearance, container handling charges, cargo handling restrictions, mandatory port services as well as a crime index (Clark et al., 2001). What becomes clear in such works is the multifaceted character of time efficiency. As defined by Suarez-Aleman et al. (2013), "port time" is the combination of several components such as port access time, loading and unloading times of cargo, ship waiting time and time for customs and other administrative procedures. The authors have particularly shown that among African ports, overall efficiency may not be always affected by time factors, especially for some ports where competition with other modes and other ports is limited.

The lack of empirical and comparative academic studies on time-related port performance indicators is surprising. It is first of all surprising considering the focus of the port and maritime industry on such metrics. As mentioned above, specialised port consultancies collect time-related port terminal performance metrics, which include average container 
handling time, crane productivity and gang productivity. Similar productivity metrics are collected by some shipping lines, e.g. Maersk with its Daily Maersk Efficiency Ranking. Moreover, various ports systematically collect the vessel turnaround times in their ports. Examples are the ports of Durban and Shanghai, as illustrated by the OECD Port-City studies on these places (Rodrigue et al. forthcoming; Hong et al. 2013). What is more, some ports have formulated targets on the average vessel turnaround times in their port: one of the maritime operations targets for the Port of Durban by the Transnet National Port Authority in South Africa is an average container ship turnaround time of 59 hours for the year $2013 / 2014$.

\section{DATA AND METHODOLOGY FOR A GLOBAL ANALYSIS OF TIME EFFICIENCY}

Time efficiency of ports is here considered to be the average time that a vessel stays in a port before departing to another port. We are aware that such a definition - and the data used for measuring it - does not specify whether it includes or not the time spent between the arrival of the ship at the entrance to the port's area of jurisdiction and the time spent to reach the berth itself, which may include passage through lock gates in some ports. Furthermore, a vessel may experience some further time awaiting for the berth to become available (a good indication of congestion), and it may then have to wait in the berth before the loading or unloading begins, so that the proposed measure of time efficiency should not be fully considered as an indicator of port/terminal efficiency. It was impossible to use more precise data at world level to compare ports. Port time can be known through detailed vessel movement data, as the large majority of port calls will be connected to loading or unloading. Very brief port stays could be connected to re-fuelling, whereas very long port stays could be connected to repairs or other reasons. The best source for analysing in detail and at global level this time efficiency appeared to be the daily movements of fully cellular container vessels collected and published by Lloyd's List Intelligence (LLI). Data was obtained for the months of May 1996, 2006, and 2011. Although the exact time (hours, minutes) of vessel arrival and departure is known in 2011, it was not considered in this study to maintain comparability with 1996 and 2006 on a daily basis and because such precise information was not released for all port calls. Data for the year 2001 was, unfortunately, not accessed due to high costs. The month of May was chosen for no other reason than the availability of only this month for the year 2011 , forcing the study to apply the same period to other years, although some authors have argued that the month of July would better reflect annual traffic averages (Wang and $\mathrm{Ng}, 2011$ ). The risk of including noncargo-related calls ${ }^{5}$ was lowered thanks the possibility excluding passage movements, but re-fuelling (bunkering) calls could not be distinguished from cargo loading/unloading calls. Canals and strategic passages, as well as "non-port" locations (e.g. countries, straits, continents, seas, etc.) were excluded from the dataset. The whole dataset results in 1050 ports situated in 164 countries.

Based on the cleaned dataset of daily vessel movements it was possible to calculate the average turnaround time (ATT) of container vessels for every port and country of the world visited by those vessels. Of course, the significance of this ATT may differ according to the

5. Those relate with anchoring, conversion, dead, inactive, laid up, new, passage, repair, trading, and under construction. 
overall activity level of the place, such as the number of vessel calls, which widely varies across the port hierarchy. For instance in May 2006, the number of vessel calls ranged from 1 (e.g. Honolulu) to 457 (Hong Kong), which is surprising for a port such as Honolulu given the fact that it is called by weekly services such as those operated by Matson Line, but an indepth examination of the accuracy of movements was impossible due to the quantity of ports under study. ATT should thus be understood in relation with the volume and frequency of vessel calls, although it carries in itself part of the answer (average turnaround time per call). Another difficulty of this research was the existence of extremely long turnaround times in certain ports. In May 2006, ATT ranges from 0 (arrival and departure the same day) to 142 (i.e. vessel Min He in Yantian port) with a mean value of 1.75 days for all ports and calls. Yet, such long stays are fully part of certain inefficiency problems affecting many ports in the world such as in India ${ }^{6}$. In the end, the ATT is the average time spent in ports by all container vessels within one month of navigation.

In this paper, ATT is confronted to broader measures of port activity (see Table 2), of which traffic indicators (total, average, maximum capacity of vessels, number of vessels, number and frequency of vessel calls, total container throughput) but also network indicators. In terms of the relationship between traffic size and time efficiency, Lemarchand and Joly (2009) demonstrated that within a given maritime range, larger ports are more robust to traffic variations, market fluctuations, and external shocks due to the importance of memory effects, the presence of a well-established port community and port cluster, thus providing to the place the ability to absorb disturbances in the transport and supply chain. In addition to those factors must be noted the role of the adjacent urban economy in providing positive and dynamic externalities, besides negative ones in terms of lack of space, congestion, and land-use competition (Hall and Jacobs, 2012). Although each port is unique in the way it provides solutions to cargo handling, it is possible to investigate possible interrelations between overall traffic size of ports and their level of time efficiency. Still, many factors influence time efficiency at various levels as recalled in the previous section, such as the importance of transhipment functions, the order of the port in the liner shipping call sequence, the size of ships, but also labor unrest, low unit costs for bunkering, and in certain cases, relaxed berthing procedures at exclusive dedicated facilities (priority usage of particular berths at particular time in independently operated multi-user facilities).

While larger traffic ports are often centrally located in the global shipping network as demonstrated elsewhere (Deng et al., 2009; Hu and Zhu, 2009; Ducruet and Notteboom, 2012a), discrepancies remain, as seen for instance with Shanghai's imbalance between high traffic volume and poor centrality (Ducruet et al., 2010). In addition, different centrality measures express different dimensions (Figure 1). The use of network measures is a novel and original way to test the role of network design on time efficiency (Alvarez, 2006).

Degree centrality is the number of adjacently connected ports, while betweenness centrality is the number of occurrences on shortest routes in the graph. Eccentricity expresses to what extent a given port is topologically situated near other ports. The clustering coefficient measures the proportion of closed triangles among the maximum possible number of triangles among a given port's neighbors, with low values being illustrative of a hub-andspokes configuration ${ }^{7}$. As argued elsewhere, hub functions of ports should foster time efficiency due to many advantages such as deep-water sites, space availability, and modern infrastructure for ensuring rapid transshipment (Rodrigue and Notteboom, 2010). These four

6. http://www.essar.com/article.aspx?cont_id=51MwO2ncIx0=

7. Many ports witnessed zero values for having no cliques (i.e. ports with only one link, bridges between two unconnected neighbors, etc.). The inversed value of the clustering coefficient was preferred for non-zero values because highly dominant ports often have low clustering coefficients. 
measures are thus much complementary when it comes to compare how ports are strategically located in global maritime container flows from different perspectives. Degree centrality is a local connectivity measure showing how much a port is connected with other ports; the clustering coefficient indicates how much this connectivity is centralized or evenly distributed around each port; betweenness centrality takes into account the "global level" of the network as it is more a measure of global accessibility; eccentricity is an intermediate measure of ports' situation in more or less densely connected (or sparse) environments. The average age of vessels is another complementary measure calculated as the different between year of operation and year of built among all vessels calling at each port.

Table 2. Available indicators at port and country level in 1996, 2006 and 2011

\begin{tabular}{|l|l|l|l|}
\hline Level & \multicolumn{1}{|c|}{ Indicator } & \multicolumn{1}{c|}{ Definition } & \multicolumn{1}{c|}{ Source } \\
\hline \multirow{5}{*}{} & Total_DWT & Sum of vessel capacities & LLI \\
\cline { 2 - 4 } & Average_DWT & Average vessel capacity & LLI \\
\cline { 2 - 4 } & Max_DWT & Maximum vessel capacity & LLI \\
\cline { 2 - 4 } & Number_vessels & Total number of vessels & LLI \\
\cline { 2 - 4 } & Number_calls & Total number of vessel calls & LLI \\
\cline { 2 - 4 } & Betweenness_centrality & $\begin{array}{l}\text { Number of shortest paths on which } \\
\text { the port is situated in the network }\end{array}$ & LLI \\
\cline { 2 - 4 } & Degree_centrality & $\begin{array}{l}\text { Number of adjacently connected } \\
\text { ports in the network }\end{array}$ & LLI \\
\cline { 2 - 4 } & Hub_position & $\begin{array}{l}\text { Share of connected neighbors } \\
\text { among maximum possible } \\
\text { connected neighbors (clustering } \\
\text { coefficient) }\end{array}$ & \multirow{2}{*}{ LLI } \\
\cline { 2 - 5 } & Age_vessels & Average age of vessels & LLI \\
\cline { 2 - 4 } & Eccentricity & $\begin{array}{l}\text { Farness to all other ports in the } \\
\text { network (closeness centrality) }\end{array}$ & LLI \\
\hline \multirow{5}{*}{ Country } & Logistics_performance_index & Composite index & World Bank \\
\cline { 2 - 4 } & Port_infrastructure_quality & Composite index & World Economic Forum \\
\cline { 2 - 4 } & Global_connectedness_index & Composite index & WhL \\
\cline { 2 - 4 } & GDP_per_capita & Gross Domestic Product per capita & World Bank \\
\cline { 2 - 4 } & Number_calls & Total number of vessel calls & LLI \\
\hline
\end{tabular}

Source: Own elaboration 
Figure 1. Methodology for network measures

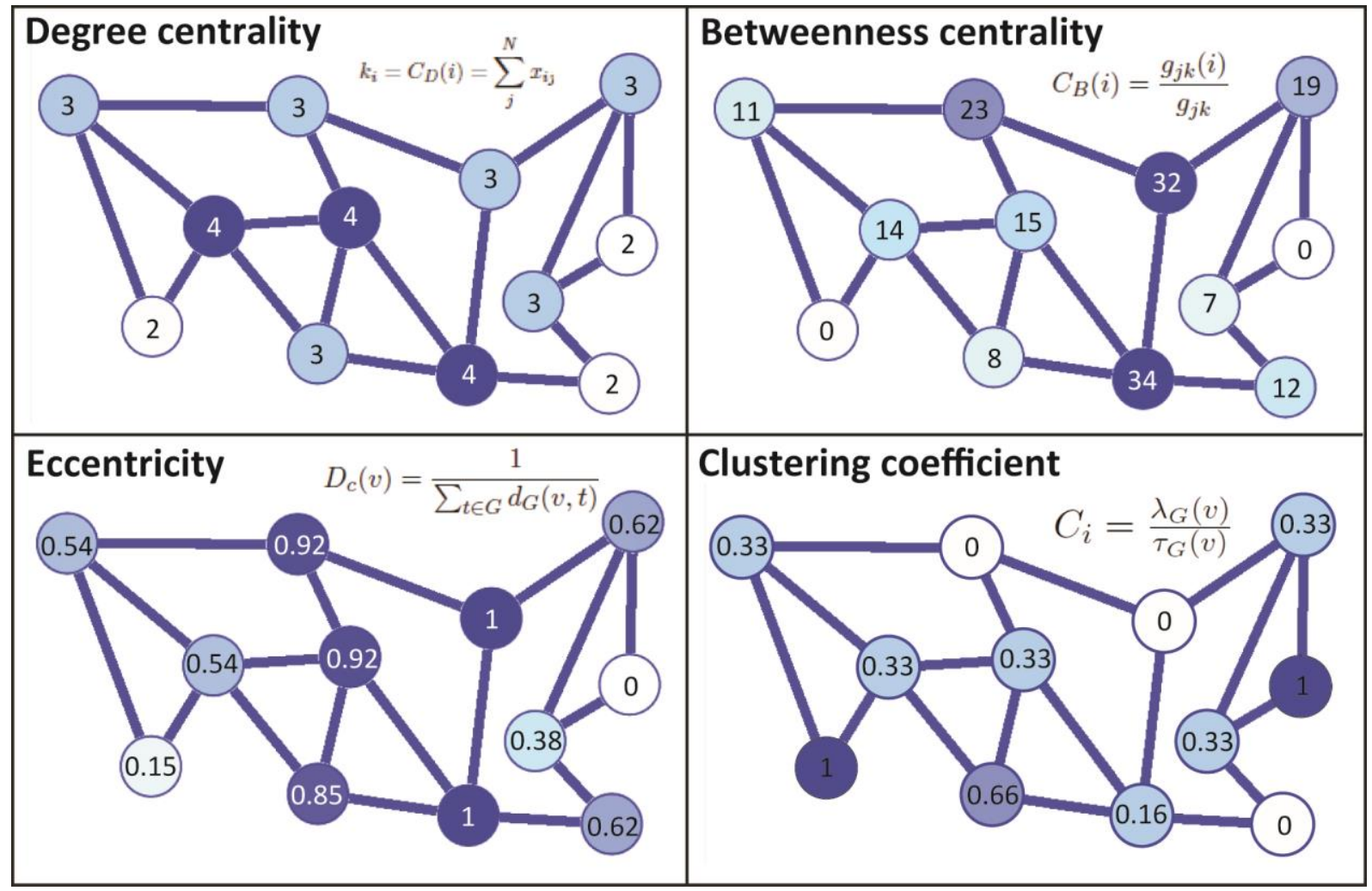

Source: Own elaboration

Subsequently, ATT is confronted with country-level indicators: the quality level of port infrastructure from the World Economic Forum (Schwab and Sala-i-Martin, 2012), the logistics competencies from the World Bank (Arvis et al., 2012), and the global connectedness from DHL (Ghemawhat and Altman, 2012). Although these composite indices are not directly related with ship and port operations, they account for the quality of the overall logistical context in which such operations take place. In addition, the total number of port calls for countries as well as the gross domestic product (GDP) per capita are included in the analysis. A multilevel analysis is used to test the latent factors (Kreft and de Leeuw, 1998; Hox, 2010) and the influence of the national context on port-level traffic and time efficiency. As observed in the next section, the geographic distribution of time efficiency (ATT) revealed important similarities among ports located in the same country or continent. Discrepancies between individual ports should therefore be explained not only by local attributes but also by national attributes, which justifies the use of such methods and such composite indicators that well summarize a country's logistical performance. Of course, large countries such as those possessing different coasts, such as the United States, include ports engaged in different trades on distinct routes, but still, those ports share affinities in terms of national port policy and strategy, planning and security, etc. thereby making the national level accurate for comparing ports. 


\section{GEOGRAPHIC DISTRIBUTION OF TIME EFFICIENCY}

\subsection{Country level}

The distribution of time efficiency among countries (Figure 2) reveals an interesting economic and political geography of the world and noticeable evolutions. Within Europe, there is a clear East-West divide in 1996, with Germany, Russia, and a number of eastern countries having a much lower time efficiency than their western counterparts, in a context of immediate post-Cold War after the fall of the USSR and the Socialist Block. Variations of time efficiency thus correspond to different technical standards and philosophies of port operations (Ledger and Roe, 1996). This is also the case of many other countries having socialist elements in the recent history of their constitution, such as Vietnam, India, Syria, Cuba, Algeria, and Libya. Other cases are often less-developed countries such as East Africa. Highest efficiencies in 1996 are mostly seen at countries with a low number of vessel calls, such as in the Caribbean, the Middle East, and Scandinavia, while China stands out by its comparatively high number of calls but very low time efficiency. Indeed, it is only in 1998 that China welcomed the first liner call from a global shipping alliance at Yantian port (Wang, 1998), most of its traffic until then being transshipped through the Hong Kong hub.

Conversely, Japan appears as the biggest country as measured by the number of vessel calls, and recorded a very high efficiency with less than one day on average for handling such calls.

The prominence of Japan is sustained in the next periods of 2006 and 2011, as its overall efficiency has even increased. This stands in contrast with other analyses of Northeast Asian liner shipping networks where main Japanese ports tended to become less dominant in terms of centrality, and increasingly polarized by other transshipment hubs such as Busan and Hong Kong (Ducruet et al., 2010). At country level however, such evolutions are blurred because Japanese ports still manage to handle efficiently vessel flows on smaller scales. Main Asian hubs have all increased their efficiency in 2006 (Asian Tigers). The East-West divide in Europe has faded away as only Russia, Ukraine, and Bulgaria witnessed a low efficiency but higher than in 1996. Countries such as Vietnam, Cuba, Syria, and Libya still perform badly, and surprisingly, China, where the number of vessel calls has increased tremendously, still ranks among the lowest time efficient countries. The rapid Chinese port growth has thus not (yet) been relayed by equivalent increase in efficiency, suggesting a gap between traffic performance and time efficiency. The map in 2006 also shows a rather stable performance of Western countries, notwithstanding the improvement of Australia and Canada, and a decline of time efficiency across the African continent, which is prolonged in 2011. 
Figure 2. Time efficiency of countries, 1996-2011

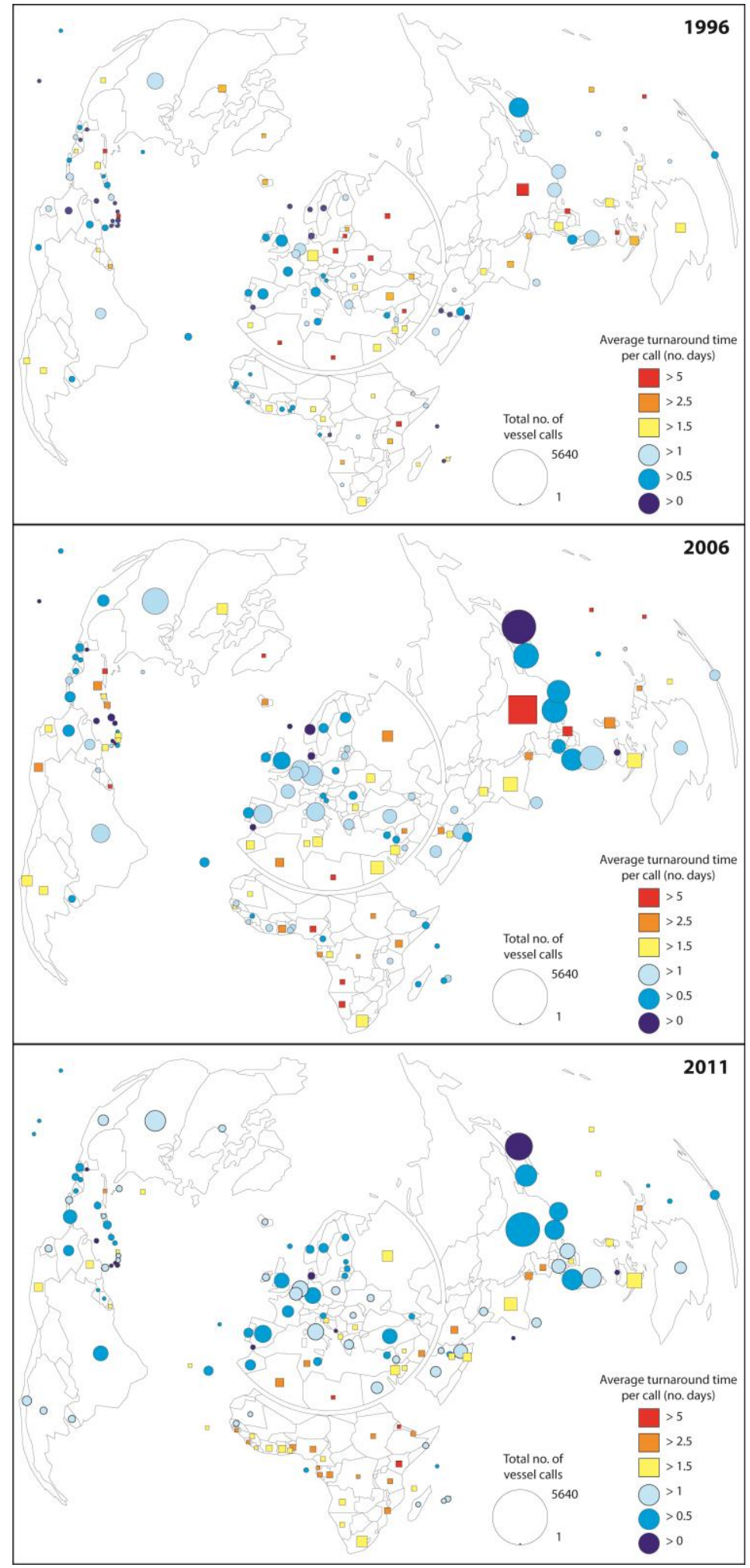

Source: Own elaboration based on LLI data 
The latter year witnessed unprecedentedly high efficiency of Chinese ports on average, which reached in only five years similar levels as Asian Tigers, notably backed by the emergence of the Shanghai-Yangshan gateway-hub that started its operations in 2005 (Wang and Ducruet, 2012), as well as the opening of very modern terminals such as the Nansha terminals in the port of Guangzhou in 2004, and the increased use of the Yantian terminal in Shenzhen in the latter half of the 2000s. All these new Chinese terminals have favourable conditions in common (deep sea access, located far away from their cities and newly designed terminals with modern equipment) that facilitated efficiency increases. Although the picture in 2011 appears to be much more homogeneous than in previous periods (see also Table 3), one can observe a persistence of a North-South divide with a concentration of more efficient countries in the northern hemisphere. The closeness between economic trends and time efficiency at country level clearly motivates this paper to further investigate the multilevel dimensions of port activity. A closer look at port-level evolutions remains necessary beforehand.

\subsection{Port level}

In 1996 and as in the previous figure at country level, we observe a concentration of higher efficiency in Western Europe, Japan, and North America, although in the latter, the Caribbean and the East Coast are better represented than Canada and the Gulf and West coasts (Figure 3). The Middle East, New Zealand, Brazil, Malaysia, and large Asian hub ports (i.e. Colombo, Singapore, Hong Kong, Kaohsiung, and Busan) have relatively lower efficiency but figure amongst efficient locations for vessel movements. Contrarily, the rest of Asian ports clearly lag behind other world ports with the worst time efficiency, together with East European ports of the Baltic and Black Sea, Montreal in Canada, Icelandic ports, and Mombasa in Kenya. Important differences are also observed between ports of the same country, such as in the United States with Los Angeles, Houston, New Orleans and Miami having a lower performance than New York, Baltimore, Charleston, and Jacksonville.

In 2006, time performance has worsened around Africa, Latin America (except for Mexico and Brazil), and in certain countries rather uniformly (Philippines). The socialist legacy of port development in planned economies is still visible in some areas as mentioned in the case of countries, with Havana being the worst performing port of the Americas. Within China, there have been improvements of time efficiency mostly in Shanghai and southern ports such as Ningbo and Xiamen, but northern ports, which are traditionally less containeroriented, have remained much less efficient (Wang and Ducruet, 2013).

In 2011 however, most Chinese ports have reached global standards with similar efficiency scores as Hong Kong, except for Tianjin, Yingkou, and Qingdao in the North, but the latter has developed Qianwan, a new port being as efficient as the majority of other ports. Ningbo and Yantai have even become China's most efficient ports in 2011. It is also since 2006 that a wave of terminal automation has taken place (after earlier experiences in Rotterdam and Hamburg), in particular in Kaohsiung, Busan and Taipei Port. The last map in 2011 confirms the decline of time efficiency all over Africa except from Moroccan ports. Differences within certain regions have faded away as seen in the Americas, although ports in Peru and northern Brazil remain less efficient, while large US ports of the West Coast still face difficulties, probably due to delays on both Asian trades and domestic hinterlands as a large volume of empty containers has to be managed. 
Figure 3. Time efficiency of ports, 1996-2011

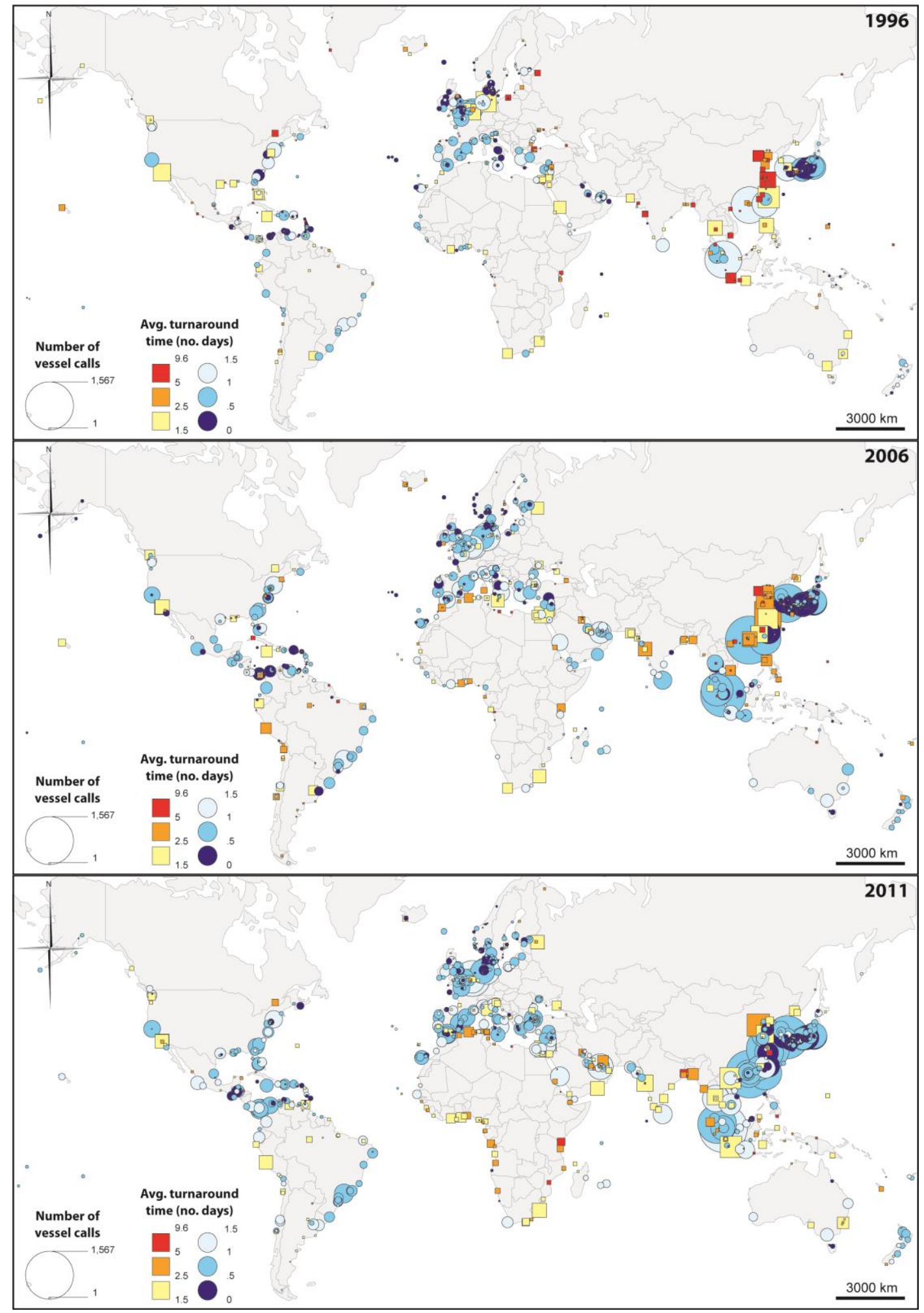

Source: own elaboration based on LLI data 


\section{STATISTICAL ANALYSIS OF TIME EFFICIENCY}

Before the regression analysis, we discuss the distribution of ATT as independent variable by regions and year (Table 3 ). This table includes not only the average (Ave.) and standard deviation (S.D.) of ATTs but also the coefficient of variance (C.V.), which is evaluated by S.D. divided by Ave., and the maximal value of ATTs (Max). This coefficient shows the standardized variable distribution on regions and years.

In 2011, ATT witnessed rather important improvements as mentioned previously, especially due to improvements in Asia (Ave. from 2.940 in 2006 to 1.397 in 2011 total). Moreover, C.V. in Asia (in 2011) is quite low (1.096) as compared to its comparatively high values in 1996 and 2006, which means comparatively small variance by the port developments in developing countries catching up with developed countries and cargo increasing by economic growth. In addition, though the ATTs in Africa are still high (2.535) in 2011, the C.V.s (0.621) are the lowest as compared to other regions ( 0.958 total). All in all, the African ports are the least efficient in recent times (Ave. 3.080).

Table 3. Descriptive statistics of ATT on regions and years

\begin{tabular}{|c|c|c|c|c|c|c|c|c|c|}
\hline \multicolumn{2}{|c|}{$\begin{array}{c}\text { Year } \\
\text { (No. ports) }\end{array}$} & \multirow{2}{*}{$\begin{array}{r}\text { Africa } \\
2.033 \\
\end{array}$} & \multirow{2}{*}{$\begin{array}{l}\text { Asia } \\
4.165 \\
\end{array}$} & \multirow{2}{*}{$\begin{array}{r}\text { Europe } \\
2.721 \\
\end{array}$} & \multirow{2}{*}{\begin{tabular}{r}
\multicolumn{1}{c}{$\begin{array}{c}\text { Latin } \\
\text { America }\end{array}$} \\
1.531 \\
\end{tabular}} & \multirow{2}{*}{$\begin{array}{c}\begin{array}{c}\text { Middle } \\
\text { East }\end{array} \\
1.211 \\
\end{array}$} & \multirow{2}{*}{\begin{tabular}{r}
\multicolumn{1}{c}{$\begin{array}{c}\text { North } \\
\text { America }\end{array}$} \\
2.473 \\
\end{tabular}} & \multirow{2}{*}{$\begin{array}{r}\text { Oceania } \\
1.845 \\
\end{array}$} & \multirow{2}{*}{$\begin{array}{l}\text { All } \\
2.618 \\
\end{array}$} \\
\hline \multirow{4}{*}{$\begin{array}{l}1996 \\
(511)\end{array}$} & Ave & & & & & & & & \\
\hline & S.D. & 2.601 & 10.948 & 8.090 & 1.783 & 0.814 & 3.023 & 2.824 & 7.127 \\
\hline & C.v. & 1.280 & 2.628 & 2.973 & 1.165 & 0.672 & 1.222 & 1.531 & 2.722 \\
\hline & Max & 16.000 & 114.000 & 90.000 & 9.000 & 3.000 & 13.000 & 16.667 & 114.000 \\
\hline \multirow{4}{*}{$\begin{array}{l}2006 \\
(707)\end{array}$} & Ave & 4.220 & 4.436 & 2.080 & 1.922 & 2.351 & 2.933 & 1.456 & 2.940 \\
\hline & S.D. & 5.907 & 10.105 & 5.002 & 2.298 & 3.703 & 6.132 & 2.021 & 6.624 \\
\hline & C.V. & 1.400 & 2.278 & 2.405 & 1.195 & 1.575 & 2.091 & 1.388 & 2.253 \\
\hline & Max & 27.000 & 84.000 & 38.000 & 13.000 & 18.600 & 31.200 & 11.000 & 84.000 \\
\hline \multirow{4}{*}{$\begin{array}{l}2011 \\
(704)\end{array}$} & Ave & 2.535 & 1.453 & 1.078 & 1.315 & 1.747 & 1.117 & 1.235 & 1.397 \\
\hline & S.D. & 1.575 & 1.592 & 1.064 & 1.113 & 1.502 & 0.700 & 0.803 & 1.339 \\
\hline & C.v. & 0.621 & 1.096 & 0.987 & 0.847 & 0.860 & 0.627 & 0.650 & 0.958 \\
\hline & Max & 8.500 & 9.500 & 9.590 & 8.574 & 7.685 & 3.122 & 3.826 & 9.590 \\
\hline \multirow{4}{*}{$\begin{array}{c}\text { All } \\
(1922)\end{array}$} & Ave & 3.080 & 3.252 & 1.887 & 1.590 & 1.819 & 2.150 & 1.538 & 2.289 \\
\hline & S.D. & 4.133 & 8.397 & 5.246 & 1.806 & 2.409 & 4.122 & 2.127 & 5.545 \\
\hline & C.v. & 1.342 & 2.582 & 2.781 & 1.136 & 1.324 & 1.917 & 1.383 & 2.422 \\
\hline & Max & 27.000 & 114.000 & 90.000 & 13.000 & 18.600 & 31.200 & 16.667 & 114.000 \\
\hline
\end{tabular}

Source: Own elaboration

The following Table 4 shows the basic statistics of ATTs based on the capacity of vessels (DWT) at ports. Based on four groups of ports each defined by a quartile, and as mentioned earlier, bigger ports are more efficient (low Ave.) and more stable (low C.V.) in terms of port 
operations. This means that port performance is related to port size, although there is no direct relationship between the two variables, ATT and traffic volume ${ }^{8}$.

Table 4. ATT variation on vessel capacities at ports (groups)

\begin{tabular}{|l|c|c|c|c|}
\hline & Ave. & S.D. & C.V. & Max \\
\hline DWT_1 (bottom 25\%) & 4.309 & 9.515 & 2.208 & 114.000 \\
\hline DWT_2 & 2.249 & 5.349 & 2.378 & 84.000 \\
\hline DWT_3 & 1.514 & 2.182 & 1.441 & 31.200 \\
\hline DWT_4 (top 25\%) & 1.336 & 1.254 & 0.939 & 15.367 \\
\hline All & 2.289 & 5.545 & 2.422 & 114.000 \\
\hline
\end{tabular}

Source: Own elaboration

The following Table 5 shows the descriptive statistics of total handling volumes (DWTs). While throughputs of North American ports are rather high, their C.V.s are low. It means that port handling sizes are more balanced. On the other hand, the DWT of Asian and European ports are more heterogeneous, as can be illustrated by their higher C.V.s. Only Oceania has seen a decrease in C.V.s. Lastly, the DWT of African ports are comparatively smaller; moreover their C.V.s are also not so high (quite compact size).

Table 5. Descriptive statistics of DWT on regions and years

\begin{tabular}{|c|c|c|c|c|c|c|c|c|c|}
\hline \multicolumn{2}{|c|}{$\begin{array}{c}\text { Year } \\
\text { (No. ports) }\end{array}$} & \multirow{2}{*}{\begin{tabular}{|l} 
Africa \\
208771 \\
\end{tabular}} & \multirow{2}{*}{$\begin{array}{c}\text { Asia } \\
1181214 \\
\end{array}$} & \multirow{2}{*}{$\begin{array}{c}\text { Europe } \\
390903 \\
\end{array}$} & \multirow{2}{*}{$\begin{array}{r}\begin{array}{c}\text { Latin } \\
\text { America }\end{array} \\
246053 \\
\end{array}$} & \multirow{2}{*}{$\begin{array}{c}\begin{array}{c}\text { Middle } \\
\text { East }\end{array} \\
430405 \\
\end{array}$} & \multirow{2}{*}{$\begin{array}{c}\begin{array}{c}\text { North } \\
\text { America }\end{array} \\
1159958 \\
\end{array}$} & \multirow{2}{*}{$\begin{array}{r}\text { Oceania } \\
158026 \\
\end{array}$} & \multirow{2}{*}{$\begin{array}{l}\text { All } \\
558581 \\
\end{array}$} \\
\hline \multirow{4}{*}{$\begin{array}{l}1996 \\
(511)\end{array}$} & Ave. & & & & & & & & \\
\hline & S.D. & 325172 & 3399812 & 1007018 & 355548 & 705608 & 1632138 & 287678 & 1805286 \\
\hline & c.v. & 1.558 & 2.878 & 2.576 & 1.445 & 1.639 & 1.407 & 1.820 & 3.232 \\
\hline & Max & 1373412 & 21329134 & 5995659 & 2129370 & 3402652 & 6993955 & 1207840 & 21329134 \\
\hline \multirow{4}{*}{$\begin{array}{c}2006 \\
(707)\end{array}$} & Ave. & 371449 & 1943255 & 766756 & 722194 & 1262404 & 1741097 & 496989 & 1107411 \\
\hline & S.D. & 612254 & 6290103 & 2180949 & 1148720 & 2164485 & 2612564 & 886615 & 3638220 \\
\hline & c.v. & 1.648 & 3.237 & 2.844 & 1.591 & 1.715 & 1.501 & 1.784 & 3.285 \\
\hline & Max & 3660970 & 55741378 & 17339432 & 7971282 & 9226778 & 9900129 & 3424649 & 55741378 \\
\hline \multirow{4}{*}{$\begin{array}{l}\mathbf{2 0 1 1} \\
(704)\end{array}$} & Ave. & 714154 & 3142916 & 1012371 & 1225625 & 1746652 & 1871443 & 646868 & 1671345 \\
\hline & S.D. & 1318199 & 9315193 & 2965316 & 2140458 & 3504233 & 2893278 & 1076813 & 5409285 \\
\hline & c.v. & 1.846 & 2.964 & 2.929 & 1.746 & 2.006 & 1.546 & 1.665 & 3.236 \\
\hline & Max & 8262710 & 69015996 & 26799073 & 12417696 & 16885864 & 11578474 & 4571494 & 69015996 \\
\hline \multirow{4}{*}{$\begin{array}{l}\text { All } \\
(1922)\end{array}$} & Ave. & 476024 & 2290127 & 769757 & 783159 & 1280278 & 1645909 & 418194 & 1196978 \\
\hline & S.D. & 954839 & 7355366 & 2338999 & 1543377 & 2686248 & 2526222 & 821955 & 4167935 \\
\hline & c.v. & 2.006 & 3.212 & 3.039 & 1.971 & 2.098 & 1.535 & 1.965 & 3.482 \\
\hline & Max & 8262710 & 69015996 & 26799073 & 12417696 & 16885864 & 11578474 & 4571494 & 69015996 \\
\hline
\end{tabular}

Source: Own elaboration

8. The same method applied to container throughputs measured in TEUs did not provide satisfactory results, mainly due to the limited availability of such figures for a large sample of world ports. For such reasons it was decided not to include TEU figures in this analysis and in the subsequent ones. Another argument is that in general, total DWT and total TEU are much correlated (Ducruet and Notteboom, 2012a) so that only one is included to avoid multicollinearity. 


\subsection{Port level}

In this part, we discuss the impact factors for ATTs applying (simple) multiple regression analysis. A multiple regression with ordinary least squares (OLS) revealed which variables most influence ATTs. As the first step, the stepwise method was used to select the variables having the most significance in decreasing order of the significant levels of independent variables as searching analysis (Goldberg and Jochems, 1961; Gujarati, 2003). As the next step, the results obtained by the first step were considered for reasonable/meaningful signs (positive/negative) and VIF, or variance inflation factor, about multicollinearity between explanatory variables. In general, the smaller VIF (less than 5.0) is better for the avoidance of multicollinearity. After a process of trial and error, the final results are discussed on the following part.

The pooling database for this regression analysis has three time periods; 1996, 2006, and 2011. Therefore, this database includes a year dummy (three time periods) and a regional (continental) dummy (seven regions, see in Tables 3 and 5), because of noticeable ATT variations across regions and years as seen in the previous section. For example, on the following estimated results, "dummy2006" shows that the data in 2006 is 1, otherwise 0. Moreover, this part takes regression analysis for not only ATTs but also the total vessel capacities (DWT) at ports as dependent variables, because the ATTs are quite different from the port handling levels at ports on the previous table. Therefore, this paper confirms the impact of DWT, for example the port operational efficiency (ATT) will also affect DWT.

Table 6 shows stable and well-fitting estimated results after various testing ( $\operatorname{Adj} R^{2}$ 0.309). The signs for variables are also in line with expectations. For example, for the ATTs at ports (smaller values mean efficient operations), total DWT traffic (natural log) and call frequency have a negative effect on ATT. Larger ports with a high frequency of vessel trips are more efficient than smaller ports and those handling more irregular trade. On the other hand, average traffic size of vessel calls has a positive effect, or the port which has bigger ships face physical challenges, like water depth and handling space at land. Although larger ports tend to handle larger vessels, larger volumes can also be explained by a high frequency of smaller vessels. This is in accordance with previous maps where a majority of smaller ports, especially in developed countries, exhibited a relatively high efficiency, as seen for instance in Scandinavia. Ports handling smaller vessels also face lesser operational restrictions. In complement, the network index of eccentricity (eccent) plays a positive role. This means that less efficient ports may not locate, in topological terms, at the periphery but near other ports; this underlines the fact that congestion can only take place in a busy environment. Indeed in 2006, the year dummy with a positive sign, many large and efficient ports have a low eccentricity, such as Singapore and Gioia Tauro, but also least efficient ports such as Yantian and Chiwan (Shenzhen terminals) in China, and Kingston in Jamaica. Thus, centrally located ports in the network are not necessarily time efficient, as this inefficiency is compensated by economies of scale and traffic amounts, as well as other benefits such as lower labour costs.

With respect to dummy variables, the ports in Africa and Asia tend to be less efficient in terms of ATT (higher ATT scores on average, 3.080 and 3.252 respectively, cf. China effect) as seen in previous tables. Lastly, year dummy (2006) is also positive, that is: inefficient. For Asia, the reason is the wider diversity of their situations (Ave. 3.252; C.V. 2.582), with huge contrasts between some efficient ports (Asian Tigers, Japan), and a majority of less efficient ports (the rest), together with the China effect (large traffics with low efficiency, except in 2011). In addition, African ports are also inefficient in 2006 (Ave. 4.220). 
Table 6. Multiple regression analysis for ATTs at ports

\begin{tabular}{|l|c|c|c|c|c|}
\hline \multicolumn{1}{|c|}{ Parameter } & Estimator & S.E. & t-value & Sig. & VIF \\
\hline Const. & 9.927 & 0.816 & 12.159 & 0.000 & \\
\hline P_totalDWT_LN & -0.964 & 0.101 & -9.504 & 0.000 & 3.313 \\
\hline P_avgDWT & 0.000 & 0.000 & 5.253 & 0.000 & 2.368 \\
\hline P_Eccent & 3.986 & 1.257 & 3.172 & 0.002 & 2.136 \\
\hline P_call-freq & -0.576 & 0.145 & -3.970 & 0.000 & 1.264 \\
\hline dummy2006 & 0.689 & 0.260 & 2.652 & 0.008 & 1.109 \\
\hline dummyAfrica & 0.853 & 0.416 & 2.051 & 0.040 & 1.055 \\
\hline dummyAsia & 1.788 & 0.287 & 6.232 & 0.000 & 1.097 \\
\hline Adj $R^{2}$ & \multicolumn{7}{|l}{0.309} \\
\hline
\end{tabular}

Source: Own elaboration

Table 7 shows the estimated results for port handling volumes (natural log). This estimated result is more fitted than the results for ATTs (Adj $R^{2} 0.911$ ). Moreover, more variables are statistically significant. The positive effects for DWT are maximum and average port handling (DWT). The bigger ships favour bigger traffics. Moreover, the number of calls (calls) is also positive impact. The higher frequency (call-freq) increases traffic volumes (cf. large shortsea ports such as Rotterdam). About the network indexes, the eccentricity (eccent) has a positive influence on traffic volume, because the ports connected closely to all other ports can take more opportunities to catch traffics on major routes. In addition, the network index of port cluster (cluster) has a positive influence on traffics. This expresses the ability of certain ports to "dominate" their direct neighbouring ports. More dominant ports locally will have larger traffics.

On the other hand, there is a negative effect for vessel capacities with ATT. More efficient operational ports (low ATT) can attract more vessels (so have higher vessel capacities). With regards to the betweenness centrality (Betw; number of occurrences on shortest paths in the graph), a positive sign will be expected for this index. A port can be "topologically" central in the graph without necessarily handling large traffic volumes, especially in the case of regional hubs. This was particularly stressed by the work of Ducruet et al. (2010) on Northeast Asian liner shipping networks, in which Hong Kong, Busan, and Incheon witnessed strong (and increasing) betweenness centrality despite lower traffic volumes (and growth), and conversely, Chinese ports went through rapid traffic growth in volume but not in centrality. Lastly, the variable for vessel age (age-vessels) shows that older vessels imply less traffic volumes. This is in line with expectations, because older vessels mean lower technical standards and also lower tonnage/TEU capacity (and small). In other words, younger vessels have more probability to be the new containerships.

With respect to dummy variables, dummy2011 has a positive impact because of higher cargo volumes. The regional dummy variables for Asian and European ports are negative impacts, because of comparatively much diverse ports size (C.V.S for DWT are 3.212 and 3.039 in Asia and Europe respectively). For example, Europe possesses plenty of small ports (short-sea and coastal shipping) like Japan (high density of small ports). 
Table 7. Multiple regression analysis for total handling volumes (DWT) at ports

\begin{tabular}{|l|c|c|c|c|c|}
\hline Parameter & Estimator & S.E. & $t$-value & Sig. & VIF \\
\hline Const. & 6.520 & 0.146 & 44.706 & 0.000 & \\
\hline P_maxDWT & 0.000 & 0.000 & 16.333 & 0.000 & 5.373 \\
\hline P_Eccent & 4.919 & 0.200 & 24.623 & 0.000 & 1.866 \\
\hline P_Cluster & 0.206 & 0.016 & 13.255 & 0.000 & 1.781 \\
\hline P_call-freq & 0.286 & 0.024 & 11.802 & 0.000 & 1.225 \\
\hline P_avgDWT & 0.000 & 0.000 & 9.952 & 0.000 & 4.006 \\
\hline P_ATT & -0.028 & 0.004 & -7.147 & 0.000 & 1.077 \\
\hline P_calls & 0.004 & 0.000 & 12.912 & 0.000 & 3.765 \\
\hline P_Betw & -0.000 & 0.000 & -10.712 & 0.000 & 3.410 \\
\hline P_age-vessels & -0.017 & 0.003 & -4.899 & 0.000 & 1.102 \\
\hline dummy2011 & 0.473 & 0.047 & 10.044 & 0.000 & 1.266 \\
\hline dummyEurope & -0.327 & 0.051 & -6.410 & 0.000 & 1.385 \\
\hline dummyAsia & -0.324 & 0.058 & -5.627 & 0.000 & 1.526 \\
\hline Adj $R^{2}$ & \multicolumn{5}{|l}{} \\
\hline
\end{tabular}

Source: Own elaboration

\subsection{Multilevel}

The wider socio-economic and country situation is analysed through a multilevel analysis by (Liner) Mixed (effect) Model with REML (restricted maximum likelihood) as a means testing the latent factors for residuals on (simple) multiple regressions (Kreft and de Leeuw, 1998; Hox, 2010). This part takes multilevel analysis based on the pooling database used in the previous section. In addition to the former database, this one includes some economic and logistics variables on country level.

As seen in Table 8, fixed part (or fixed effects) underlines which parameters have the same influence over ports and countries, while random part (or random effects) focuses on their variances between countries. Moreover, this multilevel analysis is constructed by two levels; first level is port and second level is country. While Tables 6 and 7 present the results from simple multiple regressions for checking the consistency of both results, Tables 8 and 9 describe also the variances of parameters (or random effects) for port variables on countries. In other words, the parameters on random part differ significantly on sampling areas (or countries) for this global database. Other parameters of variables are stable across countries. The model fitness of estimated functions was improved by including second (country) level variables. For example, the deviance of the model with only first level for ATT (DWT) was 11275.787 (4935.574) (smaller is better, see Table 8 and 9). In general, the signs of variables at the first (port) level are consistent with the results of the multiple regressions.

With regards to the newly statistically significant variables, the total number of vessel calls (calls) has an opposite sign at port level and county level. It is positive for port level and negative for country level. On the country level, vessel calls indicate much opportunity and attractive for global shipping network, as seen with Japan; however at port level, this indicates a congestive situation. This situation will be supported by the negative sign of call frequency (callfrep). High shipping frequency fosters efficient terminal operations, but many shipping movements reduce the efficiency by different operations, like setup costs.

With respect to dummy variables, North America and Asia have a positive sign, although for 2006, North American ports in general performed much better than Asian and African ports in terms of ATT (see Table 3). This result might be explained by the fact that a number of large North American ports, such as Los Angeles, Vancouver, Montreal, and New Orleans, performed much less than their direct neighbours. Lastly, GDP per capita (natural log) at national variable has negative sign, or positive effects for port efficiency. Richer and more 
developed markets thus suggest more efficient port operations as illustrated in the previous maps and despite some exceptions.

When it comes to random effects, average DWT (avgDWT) at port is the only significant variable except the constant term. This means that ATT differs only between countries (constant) while the impact on ATT also differs according to the average size of vessels. Because each country has a different market size, the needed ship size is also different. Otherwise, if relatively smaller ports attract larger vessels for economies of scale, port operations will be affected.

Table 8. Multilevel analysis for ATTs at ports

Fixed effect

\begin{tabular}{|l|c|c|c|c|}
\hline \multicolumn{1}{|c|}{ Parameter } & Estimator & S.E. & t-value & Sig. \\
\hline \multicolumn{1}{|c|}{ First level (port) } & & & & \\
\hline Const. & 13.689 & 1.534 & 8.926 & 0.000 \\
\hline P_Eccent & 3.551 & 1.318 & 2.694 & 0.007 \\
\hline P_calls & 0.003 & 0.001 & 1.845 & 0.065 \\
\hline P_callfreq & -0.330 & 0.152 & -2.179 & 0.029 \\
\hline P_totalDWT_NL & -1.013 & 0.117 & -8.683 & 0.000 \\
\hline P_avgDWT & 0.000 & 0.000 & 4.538 & 0.000 \\
\hline dummy2006 & 0.671 & 0.261 & 2.574 & 0.010 \\
\hline dummyAsia & 1.861 & 0.563 & 3.305 & 0.001 \\
\hline dummyNorthAmerica & 2.437 & 1.126 & 2.165 & 0.034 \\
\hline Second level (country) & & & & \\
\hline C_GDPpc_LN & -0.340 & 0.133 & -2.559 & 0.011 \\
\hline C_calls & -0.001 & 0.000 & -3.730 & 0.000 \\
\hline
\end{tabular}

\section{Random effect}

\begin{tabular}{|c|c|c|c|c|c|}
\hline \multicolumn{2}{|c|}{ Parameter } & Estimator & S.E. & Wald's Z & Sig. \\
\hline \multicolumn{2}{|c|}{ Residual error } & 25.341 & 0.866 & 29.251 & 0.000 \\
\hline Const. & Var. & 0.964 & 0.368 & 2.622 & 0.009 \\
\hline P_avgDWT & Var. & 0.000 & 0.000 & 2.583 & 0.010 \\
\hline
\end{tabular}

\section{Model fitness}

\begin{tabular}{|c|c|}
\hline Deviance & 11237.278 \\
\hline AIC & 11243.278 \\
\hline BIC & 11259.799 \\
\hline
\end{tabular}

Source: Own elaboration

Note: For example, only for the database in 2011, LPI is significantly negative for ATT. However, by applying the pooling database, this variable is not significant. Therefore, the cross section analysis (or single year) will be also needed for detailed discussion.

The following Table 9 shows estimated results for DWT by multilevel analysis. The signs of significant variables on multiple regressions are perfectly same for these results, or our regression analysis obtains more stable (reasonable) results. In addition to the above variables (see Table 7), North America dummy is positive sign as dummy variable. This region has much port cargo compared to other regions.

With respect to country variables, GDP per capita (natural log) has a significantly negative sign. In general, port cargo throughput and national economic level have tight connection, or the correlation coefficients will be positive. However, our database has much diverse countries and traffic is counted at port level (individual terminals or transport nodes). For example, China, like a number of other large developing countries, generates much port cargo, but its GDP per capita remains lower than average. That is the reason why the sign for GDP per capita is negative. 
Table 9. Multilevel analysis for total handling volumes (DWT) at ports

Fixed effects

\begin{tabular}{|c|c|c|c|c|}
\hline Parameter & Estimator & S.E. & $t$-value & Sig. \\
\hline \multicolumn{5}{|c|}{ First level (port) } \\
\hline Const. & 7.437 & 0.226 & 32.953 & 0.000 \\
\hline P_Betw & -0.000 & 0.000 & -8.208 & 0.000 \\
\hline P_Cluster2 & 0.303 & 0.024 & 12.523 & 0.000 \\
\hline P_Eccent & 3.700 & 0.191 & 19.418 & 0.000 \\
\hline P_calls & 0.019 & 0.002 & 12.928 & 0.000 \\
\hline P_ATT & -0.035 & 0.006 & -5.931 & 0.000 \\
\hline P_callfreq & 0.285 & 0.022 & 13.084 & 0.000 \\
\hline P_maxDWT & 0.000 & 0.000 & 10.422 & 0.000 \\
\hline P_avgDWT & 0.000 & 0.000 & 11.448 & 0.000 \\
\hline P_agevessels & -0.012 & 0.003 & -3.857 & 0.000 \\
\hline dummy2011 & 0.380 & 0.044 & 8.652 & 0.000 \\
\hline dummyEurope & -0.126 & 0.079 & -1.598 & 0.111 \\
\hline dummyNorthAmerica & 0.507 & 0.164 & 3.094 & 0.002 \\
\hline dummyAsia & -0.183 & 0.084 & -2.183 & 0.030 \\
\hline \multicolumn{5}{|c|}{ Second level (country) } \\
\hline C_GDPpc_LN & -0.064 & 0.023 & -2.779 & 0.006 \\
\hline
\end{tabular}

Random effects

\begin{tabular}{|l|l|c|c|c|c|}
\hline \multicolumn{2}{|c|}{ Parameter } & Estimator & S.E. & Wald's Z & Sig. \\
\hline Residual error & 0.543 & 0.020 & 27.136 & 0.000 \\
\hline P_Betw & Var. & 0.000 & 0.000 & 1.724 & 0.085 \\
\hline P_Cluster2 & Var. & 0.019 & 0.005 & 3.811 & 0.000 \\
\hline P_calls & Var. & 0.000 & 0.000 & 3.534 & 0.000 \\
\hline P_ATT & Var. & 0.000 & 0.000 & 1.527 & 0.127 \\
\hline P_avgDWT & Var. & 0.000 & 0.000 & 1.966 & 0.049 \\
\hline
\end{tabular}

Model fitness

\begin{tabular}{|c|c|}
\hline Deviance & 4613.259 \\
\hline AIC & 4625.259 \\
\hline BIC & 4658.380 \\
\hline
\end{tabular}

Source: Own elaboration

With regards to random effects, many variables are significant compared with the regression for ATT. This means that the impact scales for DWT are quite different (vary) on countries. For example, ATT (first level) negatively affects DWT, or more efficient ports will generate more traffics. However, the impacts for DWT are significantly different on countries, as no specific country-level variable stands out in the analysis. 


\section{DISCUSSION AND CONCLUSION}

This research has mapped and analysed for the first time the average number of days that container vessels need to enter and exit ports of the world. Such a measure was interpreted on the level of ports and countries as an indicator of efficiency, in a context of fierce competition within and between complex logistics and supply chains. Main results pointed at the multifaceted nature of time efficiency. Geographically, its distribution recalls well-known spatial patterns of socio-economic well-being across the globe, with a persistence of more advanced countries being more time efficient, namely Western Europe and Japan, but with noticeable deviations caused by the specificity of container shipping network design in certain areas. North American ports, for instance, appeared to be far less efficient than the Gross Domestic Product per capita of their host countries would imply, because of a concentration of modern container terminals in the Caribbean for interlining and hub-andspoke transfers on related routes. The recent and rapid economic growth of many African countries that is more based on the bulk shipping of voluminous natural resources was not reflected in the evolution of time efficiency for containers, which dramatically deteriorated from 1996 to 2006 and 2011, the years under study. Although China has tremendously increased its port activity over the period, it is only between 2006 and 2011 that the impacts of new investments in state-of-the-art port and terminal facilities on time efficiency have become visible.

Based on this geography of time efficiency, one important question tackled in this paper has been the extent to which the situation of individual ports depends on the situation of countries and regions where they are located, and the multi-level determinants of time efficiency and port activity as a whole. While larger ports (as measured by the total deadweight tonnage of all vessels having called at the port) are on average more time efficient, due to their ability to offer modern terminal handling facilities, other aspects of port activity than the sole traffic size were taken into account by means of multiple regression analyses. It appeared that call frequency, alongside traffic size, favoured time efficiency, and this trend was most represented in 2006 and in Asian and African ports (lower efficiency). Conversely, the average turnaround time negatively affected traffic size, but also the average age of vessels and the betweenness centrality of ports. Such results confirmed that operational indicators should be complemented with functional indicators. While eccentricity (proximity to other ports in the network) diminishes time efficiency as it implies a situation on major routes, it increases the probability to handle larger traffic volumes. Further research may integrate in this analysis a parameter of distance to main trunk lines as in the study by Zohil and Prijon (1999) on the determinants of transshipment volumes in the Mediterranean basin.

Our assumption that the time efficiency of ports is largely influenced by a national and/or regional situation was confirmed by the positive influence of GDP per capita and of the number of calls on time efficiency. However, three composite indices about logistics performance, port infrastructure quality, and global connectedness, did not play a statistically significant role on time efficiency. Only the Logistics Performance Index (LPI) played a significant role in reducing average turnaround times at ports for the year 2011, but this research has provided only the results from the pooling database for the sake of 
space and compactedness. Among the network indicators mobilized in this study, only the eccentricity of ports played a significant role. Betweenness centrality, degree centrality, and the clustering coefficient (hub_position) had some significance only when trying to explain traffic volumes. The assumption that specific network dimensions can explain time efficiency levels across individual ports thus has not been fully validated. More classic measures of traffic levels sufficed to explain time efficiency for a large part. Interestingly, although network indicators are much correlated with each other for the largest ports, high variability remains among the smaller ports. This explains why eccentricity and not the other indicators play a role in lowering time efficiency, as unlike other indicators, eccentricity is higher at nodes situated in denser environments.

The ways by which container ports may improve their time efficiency are threefold, through either ship-to-shore operations, other terminal operations, and/or port functions as a whole. The implementation of schedule optimalisation, vessel queuing systems and the modernization of terminal facilities, such as expansion of entrance and departure channels, upgrading of cranes, shall allow quicker operations (i.e. double cycling, tandem, and multiple lift cranes) backed by qualified personnel able to achieve high crane productivity rates (see Kiani et al., 2006). A higher number of cranes evidently increases vessel turnaround time, but there are decreasing marginal returns to scale and there are trade-offs with financial port performance indicators and berth allocation problems (Golias et al., 2009). Dedicated terminals with tightly scheduled ship arrivals can achieve higher berth occupancy levels without congestion, in comparison with common-user terminals, so the creation of dedicated terminals could improve vessel turnaround times in ports. Slow steaming might have facilitated a more precisely scheduled and realised ship arrival times. Ship-to-shore operations are largely dependent on other terminal operations, including yard equipment, terminal surface, storage capacity and terminal planning; these can be bottlenecks that affect the average turnaround time of a ship. Further research may try to integrate other classic indicators of terminal handling facilities, although they are often difficult to collect and compare on a large scale (see Joly and Martell, 2003). In parallel and according to the case, good intermodal connections with the hinterland within an integrated transport system, truck appointment systems at the terminal gate, competition between different terminals and attraction of attraction of global terminal operators can favour time efficiency. Such solutions are often implemented at new port-sites outside traditional port cities where lack of space and congestion in high-density urban areas remain challenging issues. One of the contributions of this study is the complementary perspective it provides on time efficiency where continental and national factors play a vital role alongside individual port trajectories: port authorities can improve the efficiency of their ports, but their choices are to some extent determined and constrained by national conditions. 


\section{REFERENCES}

Alvarez, J.F. (2012). Mathematical expressions for the transit time of merchandise through a liner shipping network. Journal of the Operational Research Society, 63, 709-714.

Arvis, J. F., Mustra, M. A., Ojala, L., Shepherd, B., \& Saslavsky, D. (2012). Connecting to compete 2012. Trade logistics in the global economy. The Logistics Performance Index and its indicators. Washington: The International Bank for Reconstruction and Development/The World Bank.

Bichou, K. (2006). Review of port performance approaches and a supply chain framework to port performance benchmarking. Research in Transportation Economics, 24, 567-598.

Chung, K. C. (1993). Port performance indicators. World Bank Infrastructure Notes, http://siteresources.worldbank.org/INTTRANSPORT/Resources/3362911119275973157/td-ps6.pdf (accessed June 2012).

Clark, X., Dollar, D., \& Micco, A. (2004). Port efficiency, maritime transport costs, and bilateral trade. Journal of Development Economics, 75, 417-450.

Cullinane, K. P. B., \& Wang, T. F. (2006). The efficiency of European container ports: A crosssectional data envelopment analysis. International Journal of Logistics Research and Applications, 9, 19-31.

de Langen, P. W. (1999). Time centrality in transport. International Journal of Maritime Economics, 1, 41-55.

de Langen, P. W., Nijdam, M., \& Van der Horst, M. R. (2007). New indicators to measure port performance. Journal of Maritime Research, 4, 23-36.

de Monie, G. (1987). Measuring and evaluating port performance and productivity. Geneva: United Nations.

Deng, W. B., Long, G., Wei, L., \& Xu, C. (2009). Worldwide marine transportation network: Efficiency and container throughput. Chinese Physics Letters, 26, 118901.

Ducruet, C., Lee, S. W., \& Ng, A. K. Y. (2010). Centrality and vulnerability in liner shipping networks: Revisiting the Northeast Asian port hierarchy. Maritime Policy and Management, 37, 17-36.

Ducruet, C., Roussin, S., \& Jo, J. C. (2009). Going West? Spatial polarization of the North Korean port system. Journal of Transport Geography, 17, 357-368.

Ducruet, C., Lee, S. W., \& Song, J. M. (2011). Network position and throughput performance of seaports. In T. E. Notteboom (Ed.), Current issues in shipping, ports, and logistics (pp. 189-201). Brussels: Academic and Scientific Publishers. 
Ducruet, C., \& Notteboom, T. E. (2012a). The worldwide maritime network of container shipping: Spatial structure and regional dynamics. Global Networks, 12, 395-423.

Ducruet, C., \& Notteboom, T. E. (2012b). Designing liner shipping networks in container shipping. In D. W. Song, \& P. Panayides (Eds.), Maritime Logistics: A Complete Guide to Effective Shipping and Port Management (pp. 77-100), London: Kogan Page.

Edmond, E.D., Maggs, R.P. (1976). Container ship turnaround times at UK ports. Maritime Policy and Management, 4, 3-19.

Ghemawhat, P., \& Altman, S. A. (2012). DHL Global Connectedness Index 2012. Analyzing Global Flows and their Power to Increase Prosperity.

http://www.dhl.com/content/dam/flash/g0/gci_2012/download/DHL_Global_Connect ednessIndex_2012.pdf (Accessed December 2012)

Golias, M.M., Saharidis, G.K., Boile, M., Theofanis, S., Ierapetritou, M.G. (2009). The berth allocation problem: Optimizing vessel arrival time. Maritime Economics and Logistics, $11,358-377$.

Goss, R.O. (1967). The turn-round of cargo liners and its effect upon sea-transport costs. Journal of Transport Economics, 1, 75-89.

Haddad, E. A, Hewings, G. J. D., Perobelli, F. S., \& Santos dos, R. A. (2010). Regional effects of port infrastructure: A spatial CGE application to Brazil. International Regional Science Review, 33, 239-263.

Heaver, T.D., Studer, T.D. (1972). Ship size and turnround time: Some empirical evidence. Journal of Transport Economics and Policy, 6, 32-50.

Herrera, S., \& Pang, G. (2008). Efficiency of infrastructure: The case of container ports. Revista Economia, 9, 165-194.

Hu, Y., \& Zhu, D. (2009). Empirical analysis of the worldwide maritime transportation network. Physica A, 388, 2061-2071.

Hong, Z., Merk,O., Nan, Z., Li, J., Mingying, X., Wenqing, X., Xufeng, D., Jinggai, W. (2013). The Competitiveness of Global Port-Cities: The case of Shanghai - China, OECD Regional Development Working Paper 2013/23, OECD Publishing, Paris

Hummels, D. (2001). Time as trade barrier. Purdue Cyber Working Paper 7, Purdue University, Krannert Graduate School of Management.

Itoh, H. (2002). Efficiency changes of major container ports in Japan: A window application of Data Envelopment Analysis. Review of Urban and Regional Development Studies, $14,133-152$.

Itoh, H. (2013). Market area analysis of port in Japan: An application of a fuzzy clustering. Paper presented at the International Conference of the International Association of Maritime Economists (IAME), Marseille, France.

Itoh, H., Tiwari, P., \& Doi, M. (2002). An analysis of cargo transportation behaviour in Kita Kanto (Japan). International Journal of Transport Economics, 29, 319-335.

Joly, O., \& Martell, H. (2003). Infrastructure benchmarks for European ports. Paper presented at the 4th Inha - Le Havre International Conference, 8-9 October, Incheon, South Korea. 
Jones, D. A., Farkas, J. L., Bernstein, O., Davis, C. E., Turk, A., Turnquist, M. A., Nozick, L. K., Levine, B., Rawls, C. B., Ostrowski, S. D., \& Sawaya, W. (2011). U.S. import/export container flow modeling and disruption analysis. Research in Transportation Economics, 32, 3-14.

Kiani, M., Bonsall, S., Wang, J., \& Wall, A. (2006). A break-even model for evaluating the cost of container ships waiting times and berth unproductive times in automated quayside operations. WMU Journal of Maritime Affairs, 5, 153-179.

Le-Griffin, H. D., \& Murphy, M. (2006). Container terminal productivity: Experiences at the ports of Los Angeles and Long Beach. Paper presented at the METRANS National Urban Freight Conference, http://www.metrans.org/nuf/documents/Le-Murphy.pdf

Leachman, R. C., \& Payman, J. (2011). Congestion analysis of waterborne, containerized imports from Asia to the United States. Transportation Research Part E, 47, 9921004.

Leachman, R. C., \& Payman, J. (2012). Estimating flow times for containerized imports from Asia to the United States through the Western rail network. Transportation Research Part E, 48, 296-309.

Ledger, G., \& Roe, M. (1996). East European change and shipping policy. Aldershot: Avebury.

Lemarchand, A. (2000). Mesures de la valeur et des emplois, emplois et valeurs des mesures: La dynamique des ports. Paris: DATAR.

Lemarchand, A., \& Joly, O. (2009). Regional integration and maritime range. In: T. E. Notteboom, C. Ducruet, \& P. W. de Langen (Eds.), Ports in proximity: Competition and coordination among adjacent seaports (pp. 87-99). Aldershot: Ashgate.

Merk, O. (2013). The Competitiveness of Global Port-Cities: Synthesis Report, OECD Regional Development Working Paper 2013/13, OECD Publishing, Paris

Moon, W. (2013). The impact of port operations on efficient ship operation: from both economic and environmental perspectives. Paper presented at the International Conference of the International Association of Maritime Economists (IAME), Marseilles, France.

Ng, A.K.Y. (2006). Assessing the attractiveness of ports in the North European container transhipment market: An agenda for future research in port competition. Maritime Economics and Logistics, 8, 234-250.

Ng, A.K.Y., \& Ducruet, C. (2014). The changing tides of port geography (1950-2012). Progress in Human Geography (in press).

Nordas, H. K., Pinali, E., \& Grosso, M. G. (2006). Logistics and time as a trade barrier. OECD Trade Policy Working Papers, No. 35, OECD Publishing.

Notteboom, T. E. (2006). The time factor in liner shipping services. Maritime Economics and Logistics, 8, 19-39.

Poitras, G., Tongzon, J., \& Li, H. (1996). Measuring port efficiency: An application of Data Envelopment Analysis. Working Paper, National University of Singapore, http://www.bus.sfu.ca/homes/poitras/PORTS2.pdf 
Qi, X., Song, D.P. (2012). Minimizing fuel emissions by optimizing vessel schedules in liner shipping with uncertain port times. Transportation Research Part E, 48, 863-880.

Rodrigue, J. P. (1999). Globalization and the synchronization of transport terminals. Journal of Transport Geography, 7, 255-261.

Rodrigue, J.P., Cooper, J., Merk, O. (forthcoming). The Competitiveness of Global PortCities: the case of Durban, South Africa, OECD Regional Development Working Paper, OECD Publishing, Paris.

Saggar, R.K. (1970). Turnround and costs of conventional cargo liners: UK-India route. Journal of Transport Economics, 4, 53-65.

Saldanha, J.P., Russell, D.M., Tyworth, J.E. (2006). A disaggregate analysis of ocean carriers' transit time performance. Transportation Journal, 45, 39-60.

Schwab, K., \& Sala-i-Martin, X. (2012). The global competitiveness report 2012-2013. Geneva: World Economic Forum.

Slack, B., \& Comtois, C. (2013). Measuring ocean transit times of container shipping: an empirical study of the Trans Pacific trade. Paper presented at the International Conference of the International Association of Maritime Economists (IAME), Marseilles, France.

Suarez-Aleman, A., Trujillo, L., \& Cullinane, K. P. B. (2013). Estimating port efficiency through an alternative methodology: Time as an output of port efficiency. Paper presented at the International Conference of the International Association of Maritime Economists (IAME), Marseilles, France.

Talley, W. K. (1994). Performance indicators of port performance evaluation. Logistics and Transportation Review, 30, 339-352.

Tiwari, P., Itoh, H., \& Doi, M. (2003). Shippers' port and carrier selection behaviour in China: A discrete choice analysis. Maritime Economics and Logistics, 5, 23-39.

Tongzon, J., \& Ganesalingam, S. (1994). Evaluation of ASEAN port performance and efficiency. Asian Economic Journal, 8, 317-330.

Tongzon, J. (2002). Port choice determinants in a competitive environment. Working Paper, International Association of Maritime Economists, http://www.eclac.cl/transporte/perfil/iame papers/proceedings/Tongzon.doc (Accessed June 2012).

Tongzon, J. (2004). Determinants of competitiveness in logistics: Implications for the region. Working Paper, http://www.nesdb.go.th/Portals/0/tasks/dev ability/seminar/ic/08JoseTongzon-A.pdf (Accessed June 2012).

Tongzon, J., \& Sawant, L. (2007). Port choice in a competitive environment: from the shipping lines' perspective. Applied Economics, 39, 477-492.

UNCTAD (1976). Port performance indicators. New York: United Nations.

Verminen, B., Dullaert, W., \& Engelen, S. (2007). Schedule unreliability in liner shipping: Origins and consequences for the hinterland supply chain. Maritime Economics and Logistics, 9, 193-213. 
Wang, C., \& Ducruet, C. (2012). New port development and global city making: Emergence of the Shanghai-Yangshan multiayered gateway hub. Journal of Transport Geography, $25,58-69$.

Wang, C., \& Ducruet, C. (2013). Regional resilience and spatial cycles: Long-term evolution of the Chinese port system (221 BC - 2010 AD). Tijdschrift voor Economische en Sociale Geografie, 104, 521-538.

Wang, J. J. (1998). A container load center with a developing hinterland: A case study of Hong Kong. Journal of Transport Geography, 6, 187-201.

Wang, J. J., Ng, A.K.Y. (2011). The geographical connectedness of Chinese seaports with foreland markets: A new trend? Tijdschrift voor Economische en Sociale Geografie, $102,188-204$.

Wang, S., Meng, Q. (2012). Liner ship route schedule design with sea contingency time and port time uncertainty. Transportation Research Part B, 46, 615-633.

Wang, T. F., Cullinane, K. P. B., \& Song, D. W. (2003). Container port production efficiency: A comparative Study of DEA and FDH approaches. Journal of the Eastern Asia Society for Transportation Studies, 5, 698-713.

Wooldridge, C., Michail, A., \& Puig, M. (2010). Environmental performance indicators for port operations: Management, monitoring and reporting. Paper presented at the BPA Conference, http://www.britishports.org.uk/files/Chris\%20Wooldridge $\% 20$ $\% 20$ Environmental\%20Indicators\%20for\%20Ports.pdf (Accessed June 2012).

Wu, Y. C. J., \& Goh, M. (2010). Container port efficiency in emerging and more advanced markets. Transportation Research Part E, 46, 1030-1042.

Yan, J., Sun, X., \& Liu, J. J. (2009). Assessing container operator efficiency with heterogeneous and time-varying production frontiers. Transportation Research part $B$, $43,172-185$.

Zohil, J., \& Prijon, M. (1999). The MED rule: The interdependence of container throughput and transshipment volumes in the Mediterranean ports. Maritime Policy and Management, 26, 175-193. 
